\section{$\underset{\substack{\text { hommes } \\ \text { \& migrations }}}{ }$}

\section{Hommes \& migrations}

Revue française de référence sur les dynamiques

migratoires

1303 | 2013

Diasporas marocaines

\title{
Enfants valises
}

Film français de Xavier de Lauzanne (2013)

\section{Anaïs Vincent}

\section{Q OpenEdition \\ 1 Journals}

\section{Édition électronique}

URL : http://journals.openedition.org/hommesmigrations/2607

DOI : 10.4000/hommesmigrations.2607

ISSN : 2262-3353

\section{Éditeur}

Musée national de l'histoire de l'immigration

\section{Édition imprimée}

Date de publication : 1 juillet 2013

Pagination : 206

ISBN : 978-2-919040-23-0

ISSN : $1142-852 X$

\section{Référence électronique}

Anaiis Vincent, « Enfants valises », Hommes \& migrations [En ligne], 1303 | 2013, mis en ligne le 23 janvier 2014, consulté le 22 septembre 2020. URL : http://journals.openedition.org/

hommesmigrations/2607 ; DOI : https://doi.org/10.4000/hommesmigrations.2607

Ce document a été généré automatiquement le 22 septembre 2020.

Tous droits réservés 


\title{
Enfants valises
}

\author{
Film français de Xavier de Lauzanne (2013)
}

\section{Anaïs Vincent}

1 En cette période de rentrée, le système éducatif français est observé à la loupe. On débat à tout-va sur la réforme du rythme scolaire. Mais qu'en est-il de l'accueil des nouveaux migrants sur les bancs de nos écoles?

2 Thierno, Aboubakar, Dalel et Hamza sont les élèves d'une classe de FLER (Français langue étrangère renforcée). Placée sous la tutelle du Centre académique pour la scolarisation des enfants allophones nouvellement arrivés et des enfants issus de familles itinérantes et de voyageurs (Casnav), elle dépend de l'Éducation nationale. L'objectif de cette classe passerelle: le perfectionnement du français pour faciliter l'intégration dans le parcours scolaire traditionnel. Mme Legrand, leur enseignante, les accompagne pendant une année dans cet apprentissage. Exercices de diction, rédactions, interprétations, on suit sous l'œil bienveillant de la caméra le quotidien de ces nouveaux arrivants, tous venus du continent africain et très souvent clandestins.

3 Ces dispositifs facilitent-ils l'intégration de ces adolescents? Sont-ils une réponse adaptée ? Doit-on accueillir sans aucune restriction chacun de ces jeunes? En réalisant ce film, Xavier de Lauzanne apporte sa contribution au débat.

4 Sandrine Montain et Carole Gadet, deux enseignantes intervenant dans des classes d'accueil pour des jeunes migrants, initiatrices du projet, ont facilement pu convaincre le cinéaste, auteur de plusieurs documentaires remarqués, de l'intérêt de porter un regard neuf sur cette question.

On est plongé au cœur de la classe. La caméra se fait discrète. Elle observe, silencieuse, cette micro-société en train de se créer. On découvre les adolescents avec leurs peurs, leur arrogance et leur timidité. Les enseignantes les font travailler sur leurs émotions. Ils écrivent et déclament des textes poignants. En dehors des murs de l'école, ils racontent leur histoire souvent chaotique, parfois même troublée par les guerres ou l'exode. Pour diverses raisons, ils se sont retrouvés sur le sol français et le combat ne fait que commencer. Ils expriment la douleur du déracinement, la perte de leurs proches. Enfants valises, ils sont réifiés par la volonté des adultes. Impuissants, ils subissent, souffrent de perte de repères, d'instabilité. L'usage du terme "enfant valise", 
d'abord utilisé pour désigner les enfants des DOM-TOM envoyés en métropole, s'est tristement généralisé.

6 En témoignant du travail quotidien des professeurs et de la soif d'apprendre des étudiants, Xavier de Lauzanne montre la cohérence et le bien-fondé de ces dispositifs d'apprentissage. Il ne révèle jamais les failles de ce système, sauf peut-être quand, plusieurs années après le tournage, il retrouve les protagonistes de son film... Si certains s'épanouissent scolairement ou professionnellement, d'autres peinent à trouver leur voie. Ce constat en demi-teinte fait apparaitre la fragilité de ces institutions ${ }^{1}$.

\section{NOTES}

1. Voir Claire Schiff, "L'institution scolaire et les enfants migrants : peut mieux faire", in Hommes \& Migrations, $\mathrm{n}^{\circ}$ 1251, 2004. 